\title{
Students' Perspectives on College English in Institutions of Higher Learning in Central China
}

\author{
Yuan Lingjie*, Gurnam Kaur Sidhu \\ Faculty of Education, SEGi University, Malaysia
}

Received June 28, 2019; Revised September 5, 2019; Accepted September 12, 2019

Copyright $@ 2019$ by authors, all rights reserved. Authors agree that this article remains permanently open access under the terms of the Creative Commons Attribution License 4.0 International License

\begin{abstract}
English Language today, has a special position in Chinese education as it is taught as a foreign language at all education levels ranging from primary to postgraduate education. At the university level, College English is a compulsory course. The teaching and learning of English at the tertiary level witnessed a paradigm shift with the implementation of the 2016 College English Teaching Reform (CETR). This reform saw a move from a traditional teacher-centered approach to a more learner-centered communicative approach. Therefore, this paper presents students' perspectives on College English. The study involved 611 university students from two institutions of higher learning in Central China. Data were collected via a questionnaire and interviews. The quantitative findings revealed that students held moderately positive perceptions of College English in terms of its learning objectives, language skills, teaching methods and teaching resources. Nonetheless, a mixed response was indicated in the qualitative findings as a number of students felt that EFL classrooms continued to be teacher-centered with EFL class enrolments being still large and this inhibited student-teacher interactions. Hence, the three main challenges faced by students were their limited English language proficiency, minimal teacher feedback and a lack of motivation to learn English. All these findings indicated that though the CETR has some positives, it is not without its share of limitations and these shortcomings need to be addressed if the true aspirations of the CETR are to be realized.
\end{abstract}

Keywords College English, Institutions of Higher Learning, Perceptions, Challenges

\section{Introduction}

Rapid technological and economic development worldwide and people's necessity to interact and communicate globally contribute to the increasing use of English, especially among non-native speakers, which has imposed substantial challenges on the current teaching and learning of English as a Foreign Language (EFL, hereafter) at the tertiary level in China. With the impact of globalization and internationalization, EFL at the tertiary level has undergone many reforms in China since 1999. The curricula such as College English Teaching Syllabus issued in 1999, College English Curriculum Requirements issued in 2004, College English Curriculum Requirements issued in 2007 and Guidelines on College English Teaching issued in 2016 played important roles in College English Teaching (CET, hereafter) reforms.

Guidelines on College English Teaching were issued in 2016 so as to broaden and deepen CET reforms. Besides that, the reform served to meet society's needs for qualified professionals and as a guideline for instruction to non-English majors or EFL tertiary students. Guidelines on College English Teaching was launched by the Ministry of Education of China in 2016 to initiate a shift in the teaching and learning of EFL in all institutions of higher learning (IHL, hereafter) in China. This reform witnessed a shift from a traditional teacher-centered approach to a more learner-centered communicative approach.

At the university level, College English is taught to non-English majors or EFL students for the first two years as a compulsory course and an elective course for the third and fourth-year students. This 2016 College English Teaching Reform (CETR, hereafter) comprises of a number of guidelines on various aspects on the teaching and learning of EFL. It covers aspects such as the vision, mission, and goals of CET. Besides that, it also includes the following aspects: teaching objectives, teaching contents, teaching methods, teaching means, teaching resources, teaching management and teacher professional development.

Though the CETR has been implemented since 2016, to date there has been scant empirical evidence as to its effectiveness from the perspectives of stakeholders such as 
students, teachers, administrators and industry. Therefore, it is pertinent that a study should be conducted to get a better perspective of the CETR in China. Hence, this paper explores students' perspectives on College English in IHL in Central China. It is hoped that this study will offer some feedback on the implementation of the 2016 CET Reform so that necessary steps can be taken to further enhance its implementation in all IHL in China.

\section{Literature Review}

With China embracing English as a means of communication for world trade and commerce, researchers have for some time been discussing College English education as many view it as a programme of "low efficiency and effectiveness"[1]. Some researchers feel that it has been a "thorny issue that has long been identified, yet to be solved" and many feel that "it is far from being satisfactory in terms of either national or international standards"[2]. The many grouses raised led to the introduction of the CETR in 2016. With close three years past its implementation, a few teething issues have emerged with regard to aspects such as teacher-centered approaches, lack of meaningful student-teacher interactions, ignoring students' interest in learning English and inadequate teaching resources.

Scholars have highlighted the many plus points that the Guidelines on College English Teaching has brought to the table. For instance, Wang reported that the Guidelines on College English Teaching elucidates issues such as the value of College English, teaching objectives, course system, assessment, teaching methods and faculty development, with a view to facilitate reforms in CET and improve CET quality[3]. Jia, however, moved on to detail that the main purpose of the Guidelines on College English Teaching is to help college English teachers have a better understanding of the document, and provide guidance in developing English teaching syllabi and making teaching arrangements[4]. Jia discussed the Guidelines on College English Teaching from six aspects: the formulation of school-based syllabus, the establishment of curriculum system, the establishment of curriculum evaluation methods, the development of language testing, the support of information technology and the training of teachers in the CETR, with a view to formulate the syllabus, teaching mode and so on[5].

The implementation of the CETR has witnessed a shift from the audio-lingual method to the audio-visual method, from the grammar-translation approach to the communicative approach, from the teacher-centered approach to the student-centered approach. More importantly, the CETR postulates the principle of the integrated teaching methods where EFL instructors are encouraged to use a variety of learner-centered approaches such as task-based teaching, cooperative teaching, project-based teaching, and inquiry teaching. All these are geared towards the teaching concept of "teacher-guided and student-centered"[3]. According to Yang and Yuen, the teacher-centered method was widely used in College English class, and the implementation of student-centered method was hindered by the large size of College English class[6]. According to Wu, the teaching model is still based on classroom instruction and the online teaching models are not universal, such as MOOC (massive open online course), micro teaching, and flipped classroom [7]. In order to improve the current situation of College English teaching methods, more studies should be done on the use of effective teaching methods.

Despite highlighting the many benefits the CETR has offered to EFL teachers and students alike, a few scholars have addressed the teething problems and cited the following as some of the main challenges: the demand on College English teachers' professional expertise, the employment of information technology in course design, and the demand on academic performance[8]. Song further reiterated by adding that CET has ignored the students' subjective feelings and interest towards English learning[9], whilst Li highlighted issues surrounding large class size and inadequate teachers [10]. Adding to this discussion, Zhao and Wang raised the issue of insufficient and inadequate teaching resources in local colleges and universities [11].

In lieu of this, Tang and Wang explored the current situation and development trend of college English education reform and pointed out that the primary task of teachers in teaching EFL is to cultivate students' interest in language learning. They also added the need for an innovative spirit and practical ability in the process of education, so as to promote the application of innovative teaching theory [12]. Wang stated that in the new era, we should continue to strengthen the implementation of the CETR and improve CET as it encourages multilingual education[13]. Yet there are scholars like Yan who suggested that the crux to the success of the CETR lies in whether the college English teachers can transform themselves in terms of both their role as a language teacher and their further education to meet the demands of English for Specific Purposes [14].

The above discussion reveals that the CETR is not without its share of pros and cons surrounding its implementation. This calls for the need for further investigation specifically from the students who are undergoing the experience of learning EFL under the CETR.

\section{Research Methodology}

The main aim of this study was to investigate students' perceptions of the CETR. Though the original study explored students' perspectives from close to seven 
variables, this paper will, however, be guided by the following two research questions:

1. What are the students' overall perspectives on College English?

2. What are the challenges faced by students in learning College English?

The study was conducted at two randomly selected IHL located in the city of Xinxiang, Central China. This case study involved a total of 611 second-year students among whom $26.8 \%$ were male and $73.2 \%$ were female. Data for the study were collected via a three-pronged approach involving the use of a questionnaire, interviews and classroom observations. Nevertheless, this paper will only report the findings obtained from the questionnaire and interviews.

A survey questionnaire was used and it comprised four sections which explored students' perceptions on various aspects of College English such as learning objectives, language skills, teaching methods and teaching resources. Respondents were required to respond to all items in the questionnaire based on a 5-point Likert scale where a score of 1 indicated 'strongly disagree' whilst a score of 5 indicated 'strongly agree'. The survey questionnaire was prepared in English and then translated into Mandarin by an expert and then back translated into English as the best practice in translating and validating a questionnaire into the target language [15]. It was validated by a panel of three experts in the field of TESL. To investigate the reliability of the instrument, a pilot study was conducted in another IHL involving about 60 students. The pilot study findings revealed that the reliability of the questionnaire stood at 0.963 . These procedures indicated that the questionnaire was both reliable and valid.

The semi-structured interviews were conducted with eighteen students and they were referred to as Students (S) ranging from Respondents SA to SR. Interview data was thematically analyzed by using both deductive and inductive analysis to answer the research questions.

Data obtained from quantitative approach and qualitative approach were analyzed in order to present students' perspectives on College English. The quantitative data were analyzed by using both descriptive statistics (mean and standard deviation) and inferential statistics (t-test and ANOVA) with SPSS version 22. The qualitative data were categorized and analyzed to support the quantitative findings.

\section{Results and Discussion}

The following section will provide the findings of the study followed by a brief discussion of students' perspectives on College English in IHL in Central China. Students' perceptions of all the four main aspects were explored in the study, namely learning objectives, language skills, teaching methods and teaching resources.

\subsection{Students' Perspectives on College English}

From the findings displayed in Table 1, it can be seen that the students' overall perceptions of College English was moderately positive $(\mathrm{M}=3.70, \mathrm{SD}=0.51)$. They also held fair and positive perceptions with regard to CETR learning objectives $(\mathrm{M}=3.75, \mathrm{SD}=0.95)$, indicating that a majority of students positively agreed that College English helped students achieve their learning objectives. A similar sentiment was also expressed in terms of their views on language skills $(\mathrm{M}=3.69, \mathrm{SD}=0.83)$, teaching methods $(\mathrm{M}=3.77, \mathrm{SD}=0.81)$ and teaching resources $(\mathrm{M}=3.60$, $\mathrm{SD}=0.94)$. All these positive scores are indicative of the fact that students viewed College English as a good move to enhance the teaching and learning of EFL in the two selected IHL in Central China

Table 1. Students' Perceptions of College English $(n=611)$

\begin{tabular}{|c|c|c|}
\hline Items & $\mathrm{M}$ & $\mathrm{SD}$ \\
\hline Learning Objectives & 3.75 & 0.95 \\
\hline Language Skills & 3.69 & 0.83 \\
\hline Teaching Methods & 3.77 & 0.81 \\
\hline Teaching Resources & 3.60 & 0.94 \\
\hline Overall Perceptions & 3.70 & 0.51 \\
\hline
\end{tabular}

(Scale: 1=Strongly Disagree, 2=Disagree, 3=Neutral, 4=Agree, $5=$ Strongly Agree)

The quantitative findings corroborated with findings obtained during interview sessions. For instance, Respondent SB said that "College English is very important. My English language skills in listening, speaking, reading and writing are improved due to my English teacher's teaching methods. My teacher arranges time for the part of delivering speeches before the class in each semester, asks students to have group discussion in each class, and occasionally offers some writing assignments after class. So I think my skills in listening, speaking, reading and writing have been improved.”

The above findings imply that students are rather appreciative of their language teachers and this is reflected in their overall articulation of positivity. Similar findings were also recorded by Du who discovered that students' comments on College English were positive because they appreciated their teachers' hard work, responsibility and patience in teaching and coaching [16].

\subsubsection{Students' Perceptions of Learning Objectives}

Based on the items explored in this section, students indicated that College English helped to cultivate English language competence $(\mathrm{M}=3.78, \quad \mathrm{SD}=0.88)$, enhance awareness of cross-cultural communication ( $\mathrm{M}=3.81$, $\mathrm{SD}=0.87)$, improve communication skills $(\mathrm{M}=3.56$, $\mathrm{SD}=0.93$ ), develop ability of autonomous language learning $(\mathrm{M}=3.79, \mathrm{SD}=0.86)$, and enhance cross-cultural knowledge $(\mathrm{M}=3.83, \mathrm{SD}=0.85)$. As a whole, the findings showed that students had positive perceptions of learning 
objectives. This was further elaborated by Respondent SD in the interview when he said that "As long as I study hard, I can learn a lot in College English. We can know some knowledge about our major via English. Moreover, we can expose to a wider range of world. The usage of English is very extensive."

\subsubsection{Students' Perceptions of Language Skills}

Students were also in agreement that College English had helped to improve listening skills $(\mathrm{M}=3.80, \mathrm{SD}=0.65)$, speaking skills ( $M=3.69, S D=0.67)$, reading skills $(M=3.60$, $\mathrm{SD}=0.72)$, writing skills $(\mathrm{M}=3.61, \quad \mathrm{SD}=0.66)$ and translating skills $(\mathrm{M}=3.77, \mathrm{SD}=0.64)$. The interviews further highlighted that a majority of students greatly improved their listening skills and speaking skills, followed by translating skills, writing skills and reading skills. For example, Respondent SF in the interview said that "I greatly improved my skills in listening and speaking. I also improved my skills in writing and translating. In this semester, I improved my skills in listening and speaking because I focus on them. My listening skills in short conversations, sentences and short texts have been improved. I have got obvious improvements in speaking skills, especially in making everyday conversations and giving speeches."

\subsubsection{Students' Perceptions of Teaching Methods}

The mean scores indicated that students had a moderate level of perceptions of teacher-centered lecture method $(\mathrm{M}=3.84, \quad \mathrm{SD}=0.58)$ and student-centered teaching methods ( $\mathrm{M}=3.69, \mathrm{SD}=0.65)$ adopted in College English. These findings were also corroborated in the open-ended section of the questionnaire where students ranked the following as the most frequently used teaching methods: lecture teaching, task-based teaching, cooperative teaching, project-based teaching, inquiry teaching, integrated teaching, communicative language teaching and reflective teaching. This was further elaborated by Respondent SC in the interview when he elaborated that "Lecture teaching is most frequently used, followed by task-based teaching and cooperative teaching. Integrated teaching is usually used. The teaching methods are interesting. I prefer my English teacher's teaching methods."

\subsubsection{Students' Perceptions of Teaching Resources}

Students were also in agreement that the IHL had good language teaching facilities such as language lab and multimedia ( $\mathrm{M}=3.93, \mathrm{SD}=0.90)$, they had adequate access to English learning resources ( $\mathrm{M}=3.76, \mathrm{SD}=0.92)$, College English textbooks suited their needs and interests $(M=3.46$, $\mathrm{SD}=0.94$ ), and what they had learned in College English class had met their expectations $(\mathrm{M}=3.26, \mathrm{SD}=0.86)$. This was further elaborated by Respondent SE in the interview when she highlighted that "In my opinion, our university has done a good job in offering teaching resources. Every teacher uses multimedia in the class and students can use the language lab after class.” Meanwhile, some students expected to change the status quo. For example, Respondent SI stressed that "I think our facilities are not good enough. We need more computers equipped in the language labs. We also want more online learning resources."

\subsection{Challenges Faced by Students}

The second aspect examined in this study was the challenges faced by EFL students under the implementation of the CETR. Though a number of challenges were highlighted by the students, this paper will only focus on the three main challenges put forward by the students, namely, limited English language proficiency, minimal teacher feedback and lack of motivation to learn English.

\subsubsection{Limited English Language Proficiency}

A large majority (91.4\%) felt that the main challenge in learning English was their limited English language proficiency. These students admitted they were aware of the CETR and how it has focused more on skill-based communicative approach. Nonetheless, they felt that despite the implementation of the CETR, they were not able to reap the true benefits of the skill-based communicative approach due to their own language aptitude and capability in the language.

When quizzed further, Respondent SF effectively summarized the challenge as follows: "I know we have a new English curriculum and my English teacher in the university is good and is always trying to help us learn English...but the main problem is that many of us are very poor in English and do not have a good base in English so this new English curriculum cannot help us much as we are weak in English.”

Findings also revealed that students indicated limitations in all the four language skills and even translation, grammar and vocabulary. Approximately $40.2 \%$ of them stressed that they were not good at speaking English as they experienced problems with pronunciation, inadequate vocabulary and lack of opportunities due to lack of a conducive English speaking environment. A few of them highlighted that they had personality issues as they were basically shy whilst a few others admitted they were embarrassed to speak English lest they may get ridiculed by their peers. Another $30.7 \%$ of them felt they had problems in listening to English due to the limited exposure to the language and hence they experienced difficulty in comprehending English. Another 9.2\% of them felt they also faced difficulties when they had to read long passages in English as they found too many words a little intimidating. They also acknowledged that this was due to their limited capabilities in English language grammar and vocabulary. The remaining students highlighted their limitations in writing and doing Chinese-English 
translation.

Students' limited English language proficiency has been cited by numerous scholars such as Dong, that CET has shown a lack of correlation among teaching and learning [17]. Colleges and universities should attach importance to the CETR and enhance all the four language skills in terms of listening, speaking, reading, writing, and even translation, vocabulary and grammar through the use of effective English teaching methods.

\subsubsection{Minimal Teacher Feedback}

The second challenge these students highlighted focused on teacher feedback. Students stressed that even though the CETR highlighted more student-centered learning, this was not happening in their EFL classrooms. Respondent SA pointed out that "I think the new English curriculum is said to be more focused on the students, but I do not see this in my English class...I think this is because my class is very large and we have 80 to 100 students in the class...many times no one is really listening or learning anything, and the teacher is doing most of the talking...what I feel is I want more teacher's help and feedback on my English performance. For example, when I write my composition, I get a grade but I would like my teacher to tell me where I go wrong and how to improve." Interview sessions further confirmed this fact that feedback was minimal for most of their classroom presentations and assignments.

A majority indicated that they could improve if they had smaller classroom enrollments for EFL lessons especially for their speaking and writing lessons. This point was further elaborated by Respondent SE when she said that "I like to get feedback from my teacher when we do classroom presentations...my teacher usually gives us a group mark but I want to know my personal mark... what I did good and what I need to improve...if the English teacher helps us and gives us good feedback, we can improve."

The importance of teacher feedback in the EFL classroom cannot be underestimated. There is so much literature that has emphasized timely that quality and constructive feedback is important for all learning. Teacher feedback becomes even more critical for EFL learners in China as they are learning in a homogeneous environment where everyone is speaking Mandarin.

\subsubsection{Lack of Motivation}

The third challenge that student identified was the lack of motivation or commitment in learning English. They claimed that though the CETR had suggested many changes in English language teaching and learning, they were still not interested in learning English. A majority felt that though the CETR highlighted student-centered and activity-based teaching methods, their lectures were boring and their EFL classes were mainly teacher-centered. Besides that, a large majority felt that a number of them lacked the basic English language proficiency and hence they were not motivated to learn English. Respondent SD felt that "even though the world outside see English as important, many of us students are not motivated to learn English because we are poor and we do not want to work outside...as for me, I will work in China so I have to be good at studies and Mandarin.” A similar sentiment was also expressed by Respondent SE who said that "many of my friends are not motivated to learn English as we do not have a good environment to learn and practice English. We cannot practice what we have learned outside the classroom. Once we are not in the English class, we all speak Mandarin, so we are not committed to learn English."

According to Chang and Lehman, learning motivation has impact on the language learning and is a key factor which may dominate the success or failure in second language acquisition [18]. The teacher-centered method is still widely used in College English class, and the use of multimedia reduces the opportunity of face-to-face communication between lecturers and students, which may result in ignoring students' emotional changes by lecturers [6]. Hence, more student-centered teaching methods should be adopted to stimulate students' interest in learning English.

\section{Conclusions}

The findings in this study showed that even though the quantitative findings revealed students displaying moderately positive perceptions towards the implementation of the CETR, the qualitative findings showed some rather mixed responses. They held positive perspectives on College English in terms of learning objectives, language skills, teaching methods and teaching resources. A few students, however, admitted that all that was on paper, was not reflected in their EFL classrooms due to challenges surrounding their own language proficiency levels and lack of conducive environment to practice the language. They also highlighted that class enrollments were large and this inhibited student-teacher interactions leading to the old teacher-centered EFL classrooms. Therefore a number of students felt it was a lack of quality feedback that led to a lack of motivation to learn the language.

Finally, it is perhaps pertinent to note that the findings of this study are not generalizable across China due to the limited sample size. It is hoped that this study has shed some light on the implementation of the 2016 CETR and necessary actions can be taken to further enhance its implementation in all tertiary institutions in China.

\section{REFERENCES}

[1] W. Dai, "On further improving English language learning in China: suggestions for consideration”, Foreign 
Languages and Their Teaching, vol.7, pp.1-32, April 2001.

[2] G. Hu, "English language education in China: policies, progress, and problems”, Journal of Language Policy, vol. 4, pp. 5-24, March 2005.

[3] S. Wang, "An interpretation of the Guidelines on College English Teaching”, Foreign Language World, vol. 3, pp. 2-10, June 2016.

[4] G. Jia, "Methods, means and resources of English teaching in the Guidelines on College English Teaching”, Foreign Language World, vol.3, pp.11-18, June 2016.

[5] G. Jia, "Guidelines on College English Teaching and college English teaching reform”, Contemporary Foreign Languages Studies, pp. 62-65, vol.6, November, 2017.

[6] J. Yang and C. K. Yuen, "College English teaching methodology and language planning: A pilot study in Hefei, China”, Procedia - Social and Behavioral Sciences, vol.118, pp. 495-502, Febuary 2014.

[7] Y.Wu, "A study of the reform of college English teaching in posts and telecommunications universities under the guidance of Guideline on College English Teaching”, Unpublished Master Dissertation, Nanjing University of Posts and Telecommunications, Nanjing, 2018.

[8] J. Han and H. Yin, "College English curriculum reform in mainland China: Contexts, contents and changes”, Asian Education Studies, vol.1, pp1-10, February, 2016.

[9] Y. Song, "Reform and development of college English education", Advances in Social Science, Education and Humanities Research, vol. 101, pp157-161, April 2017.

[10] X. Li, “Optimize the managerial system of college English teaching”, Foreign Language World, vol. 3, pp. 27-33, June, 2016.

[11] Y. Zhao and F.Wang, "Research on the sharing of English teaching resources in local colleges and universities -Take the four universities in bengbu, anhui province as an example”, Science and Technology Vision, vol. 23, pp. 47-48, August 2017.

[12] D.Tang and H. Wang, "Research on current situation and development trend of college English education reform", Advances in Social Science, Education and Humanities Research, vol.107, pp. 195-198, December 2017.

[13] S. Wang, "Changing concepts, deepening the reform and promoting the development of college English teaching”, China University Teaching, vol.2, pp. 59-64, February 2017.

[14] S. Yan, "The implications of Guidelines on College English Teaching upon college English teaching reform and development”, pp. 32-36,109, July, 2017.

[15] S. B. Merriam, Qualitative Research: A Guide to Design and Implementation, 2nd e.d., San Francisco, CA: Jossey-Bass, 2009.

[16] H. Du, “An investigation of college English teaching in four universities in China”, International Education Journal, vol. 3, pp.71-84, February 2002.

[17] X. Dong, "Research on the teaching methods of college English”, Creative Education, vol.7, pp.1233-1236, June
2016.

[18] M. Chang and D. J. Lehman, "Learning foreign language through an interactive multimedia program: an experimental study on the effects of the relevance component of the ARCS model”, CALICO Journal, vol.20, pp.81-98, 2002. 